Gender and Social Status Differences in Using Taboo Words in Fast and Furious $1 \&$ Fast and Furious 7

Rahayu Nurazizah

Universitas Sebelas Maret

Author Note

Author is a student of English Department, Faculty of Cultural Sciences, Universitas Sebelas Maret, Jalan Ir. Sutami 36A, Surakarta, Indonesia (e-mail: rnurazizah21@gmail.com) 


\begin{abstract}
This article examines the types of taboo words employed by the male and female characters in the movies "Fast and Furious 1" \& "Fast and Furious 7". It seeks to explain the correlation between the social class and frequent use of taboo words of the male and female characters of the movies. This study design is descriptive qualitative with the movie "Fast and Furious 1" \& "Fast and Furious 7" as the sources of the data. This study applies purposive sampling technique which scrutinizes all of the utterances containing taboo words spoken by the characters as the data of the study. It is found out that there are 102 taboo words from 72 dialogues. After categorizing the data, it can be noted that obscenity is the most dominant taboo word used by the characters, both by male and female. However, male characters use it more frequently. The finding reveals that the word "shit" is dominantly used in their conversations to express anger. Moreover, the differences of social class also affect the use of taboo words. The analysis shows that middle class utters taboo words more frequently than the working class. Furthermore, the article attempts to argue that the use of taboo word is not only limited by the aspect of gender and social class that exist in society, but also the equality of rights makes taboo usage equal among the public.
\end{abstract}

Keywords: taboo words, male-female differences, social class, movie, Fast and Furious 1, Fast and Furious 7 


\section{Gender and Social Status Differences in Using Taboo Words in Fast and Furious $1 \&$ Fast and Furious 7}

Nowadays, movie is something important for our amusement when we get bored with the job or assignment. Movie is a moving picture shown in a television or cinema and it contains a story (Shobur, 2004). Shobur has mentioned that a movie is always affected and shapes the community through its messages. In fact, characters in a movie sometimes use bad word or bad language which is inappropriate to say. The use of a bad language is sometimes influenced by some factors, such as gender, age, social class, education, etc. This bad language is known as a taboo word.

Taboo word is one of the interesting aspects of language which should be avoided in the daily routine. Mbaya (2002) has stated that taboo words are any expressions which lack of morality, so they can cause offence in a conversation. Keturi and Lehmonen (2012) have explained that taboo words contain forbidden or offensive words which can trigger conflicts (p.10). In addition, Lehmonen has also said that the main purpose of using taboo words is to offend someone and make other people feel uncomfortable by any chance (p.11). Furthermore, when people use taboo words, it can reveal personal identity, character, and background of the speaker (Chaika, 1982).

The offensiveness of taboo words can rise and drop depending the condition around (Anderson \& Trudgill, 1990). In other words, a taboo can be offensive or not depending where, when, and why it is uttered. The United States, for example, is one of the countries which considers taboo word as an important issue and a big deal problem. Expressions which are correlated with sexual activity or sexual anatomy are considered as taboo in the U.S. This 
consideration is influenced by their social history which mentions that the idea about having sex was only for creating children and not for any other reason (Gao, 2013). Thus, expressions which connoted to sexual activity and anatomy were taboo because it was a sin to say it. Other expressions which are considered as taboo are words connected to racism. The United States has a long history of cruel racism with the Black people as the victim of offensive words produced by the White. After civil right movement which led to the equality between Black and White, all words which have racist connotation are considered as offensive and it is impolite to say them. Racism is one of the factors which can influence the use of taboo words. The other factors are age, gender, education, social class, etc.

There are many factors which initiate someone to utter taboo words. Age, gender, education, and social classes are background factors of why some people communicate with others with some taboo expressions, and others are not. Films are one of the media products which can be studied to understand the influence of individual background in communicating with some taboo expressions. (McQuail, 2010) Different background factors also influence reasons on taboo word choices to communicate. Some people use polite words when they are talking to someone older than them; however, others utter impolite words when, for example, they underestimate people who are less educated than them (Batistella, 2006). Gender also influences the way to communicate with others because male and female have different perception on perceiving taboo words. Generally, people from lower education or lower social class background have a tendency to use more taboo words in their conversation, despite their gender difference.

This study takes the franchise movies, entitled "Fast and Furious 1 and Fast and Furious 7' as object to study the factors which influence the characters' communication with some taboo 
expressions. These movies are one of the most popular action movies which have earned rating of $67 \%$ score, in terms of popularity, as written in Rotten Tomatoes. Meanwhile, in terms of intense sequences of violence, sexual content, drug references, and bad language, it has been rated into PG or Parental Guidance which connotes to medium offensive language and content. These movies, at a glance, tell about the American street race's life, where people race to show off their racing skill and wealth. "Fast and Furious" movies are franchise movies produced in 8 seasons up to this day. However, this study just focuses on "Fast and Furious 1" released in 2001 \& "Fast and Furious 7" released in 2015. These movies portray an illegal street racing, where a family bound and raced as the main point. LA street racer Dominic Torreto falls under suspicion of the LAPD for robberies. Brian O'Connor, an officer of LAPD, wants to join the rank of Dominic in order to convict Dominic. Unfortunately, in the middle of his job, Brian falls in love with Dominic's little sister, Mia. His feeling makes him leave his job to get Mia and gets Dominic's attention and then makes him a street race driver. During Brian's participation in Dominic's group, Brian and Dominic are gradually confronted with some situations which make them have to create a professional group to carry out their robbing mission. In recruiting these new members, Dominic's group unconsciously establishes a different new atmosphere because the characters that join the group come from different backgrounds, such as race, age, social class, and gender difference. These diversities cause differences in how to communicate each other and how to express their emotion.

The movies show how the characters use some inappropriate words to express their idea or their emotion. The movies also provide information of how different background factors, as mentioned above, influence the way to communicate with others, such as some scenes showing individuals from upper social class and higher education level tend to communicate in polite 
ways. However, it does not rule out the possibility for them to use bad words to convey their message and their intention, depending on the situation. In fact, some scenes show that many characters, despite their social classes and gender, are identified using taboo words. With a consideration of the complexity between all background factors, as mentioned previously, this study purposes to scrutinize the two films to understand the correlation between age, gender, social class, educational background and the reasons of using taboo words to communicate with others.

Previous studies investigating the correlation between gender and taboo words have found out that both male and female use strong words and there are no significant gender differences in the frequent use of taboo words. Female is recognized using strong words in conversation, so is male (Mohammadi et al, 2014; de Klerk, 1992). Mohammadi et. al., especially identifies that male tends to use more taboo words than female in only some circumstances. Meanwhile, de Klerk's research focusing on the correlation between gender and social classes, concludes that taboo words are mostly expressed by female from middle class. Thus, the social classes are the cause of the individuals in using some impolite expressions, rather than gender difference. Even though the gender prescriptions mention the requirement of women to keep their prudent and their discreet image, they still use some taboo words to show their strong or deepest emotion to others.

Other previous studies, as conducted by Soori and Sherafat; Talley and Hui-Ling; and Mohammadi, Roumiani and Tabari have only focused on the differences between male and female in using taboo words whereas, de Klerk's study only employs female as the main object in her research, which explains that social class could be one of the factors in the usage of taboo words. Yet, she has not mentioned the reasons of taboo words by male in correlation to social 
class. Thus, this study tries to examine how social class and gender influence the usage of taboo words in two movies produced in two different years. The study intends to scrutinize the type of taboo words, the frequency of use in conversation based on gender, and the social class of the characters who use them. It attempts to examine the correlation between social class and gender and also to identify the possible shift on its usage in different time.

\section{Methodology}

This research focuses on the use of taboo words by the male and female characters from different social classes in two movies produced in different time. The sources of data are the movies "Fast and Furious 1" (2001) and "Fast and Furious 7" (2015) which are directed by Rob Cohen and James Wan. Moreover, for collecting the primary data, the study takes the dialogues and monologues of the characters and for the purpose of collecting secondary data, it takes some implicit backgrounds, such the characters' situation when communicating, social classes and educational background. These movies are taken as the objects to understand the correlation between the usage of taboo words with gender and social classes because these two movies present the complexity of United States social life which can trigger any unexpected situation because of differences of social classes and gender. In such situation, the characters, both the male and the female, can use taboo words to express their emotion. Although the rating of the two movies suggests that these movies are suitable for young audiences, $15+$ with parental guidance, these two movies provide many scenes which show the usage of taboo words of the characters in doing communication.

Furthermore, in analyzing the types of taboo words used by the characters from different social classes in "Fast \& Furious 1" and "Fast \& Furious 7", the study applies descriptive qualitative method. Descriptive qualitative approach is used because this study involves the 
collection of data for the purpose of describing the existing condition. The steps include searching, collecting, classifying, analyzing the data, interpreting and drawing the conclusion (Surakhmad, 1994:147). The collected data are the subjects of research; the study attempts to arrive at a rich description of the people, objects, conditions, events or conversations and so on. Driven by the phenomenon, this study uses content analysis method. The classification of the data includes the types of taboo words used and the social classes of the characters uttering these words. Besides, it also looks at the different ways of communication between male and female when triggered by unexpected situation which could explode their emotion.

This descriptive qualitative research employs the purposive sampling technique by collecting the data based on Batistella's (2005) types of taboo words and Gilbert's (2005) concept of social classes. Furthermore, this study is conducted by watching the movies, identifying and classifying the selected data e.g. the taboo words expression, the social classes, and the different communication between male and female, and then it is followed with data interpretation. There are 59 varieties of taboo word expressions found in 40 dialogues for the movie Fast and Furious 1 and 43 varieties of taboo word expressions found in 32 dialogues for the movie Fast and Furious 7.

Edwin Batistella's conception of the types of taboo words (2005) is used as the tool to examine the data. Because this study also attempts to understand the different ways of communication between male female in perceiving and using taboo words, this study also pays special attention to situations when the male and female characters are communicating and the context of communication. In relation to the gender socialization which prescribes different style of communication between male and female which leads to the different conception of morality 
between male and female, this study has a hypothesis that there are possible differences for the man and the woman in expressing their emotion with some taboo words.

The last concept used in this article is the social classes. It is used to examine the difference between the upper class and lower class in using taboo words. The study prefers to use the condensation of Gilbert's and Joseph Kahl's (2005) theory, summarized into four types of social class in general. The condensation is used to make the analysis easier in identifying and classifying the data. To further answer the question of the types of taboo words used by male and female characters from different social classes; this research uses some codes to identify and analyze them. Coding data in this research is conducted through categorizing the data into the number of each datum consisting taboo word; the number of the dialogue with taboo words; the sex differences; the social classes differences; and the types of taboo words (e.g. 5/Dlg5/Male/MC/Profanity).

\section{Result}

The data are gathered thoroughly and also analyzed. The variables which are types of taboo words, male female differences, and also social classes are coded and analyzed. From the coded and analyzed data in Fast and Furious 1 and Fast and Furious 7, there are 102 data containing taboo words found in 72 dialogues. The 102 taboo words as the data are classified into the types of taboo word based on Batistella's (2005) concept: epithets, profanity, vulgarity, obscenity.

\section{Epithets}

$00: 12: 43 \rightarrow 00: 13: 38$

Deckard : "You are a terrible liar."

Hobbs : "Damn IT guys!” (63/Dlg43/Male/MC/Epithets) 
In this conversation, Hobbs uses the taboo word damn to curse the Information Technology people since they carelessly store the important files on Hobbs' computer. Hobbs feels annoyed because the important information can be accessed easily by people who do not have the access permission. The word damn in Hobbs' statement contains anger and a curse so that this word belongs to the type of epithets.

\section{Profanity}

$02: 01: 50 \rightarrow 02: 02: 15$

Letty : "Why did not you tell me we were married?"

Dominic : "Because you cannot tell someone they love you.

\section{Roman : "Holy shit.” (101/Dlg71/Male/MC/Profanity)}

This scene shows that Dominic gets injured after having a battle with his rival. This case makes Roman utter the taboo word holy shit to express his surprise concerning Dominic's condition. Yet, Roman does not intend to use this word to curse someone, but he uses it to show his grateful knowing that Dominic has got conscious. The word holy shit is related to a religious term. The word is compounding word from holy and shit. This term refers more to the word holy rather than the word shit which makes it classified into profanity taboo word.

\section{Vulgarity}

$00: 26: 27 \rightarrow 00: 26: 57$

Brian : "So what about you?"

Dominic : "Two years in Lompoc. I will die before I go back.... Oh, great!" Brian : "What?" 
Dominic : "It is going to be a long ass night. That is what."

\section{(19/Dlg14/Male/WC/Vulgarity)}

The word long-ass used by Dominic explains that he feels surprised about their condition at that time. Dominic is a little surprised realizing something he should not have done in that place. Basically, the word ass is used to call someone who does silly things but in Dominic's sentence, he does not mean it. It is just a term of swearing used by Dominic to express his feeling. Since the word ass has the meaning as a part of human body so it belongs to vulgarity type whereas the intention does not mean to mention the part of human body.

4. Obscenity

$00: 21: 19 \rightarrow 00: 21: 28$

Edwin : "Hey, Monica. What is up, baby?"

Monica : "What is your problem? You did not win."

Edwin : “Fuck you then!” (16/Dlg11/Male/WC/Obscenity)

In this conversation, Edwin utters fuck to show his annoyance to Monica. He is angry because Monica does not want to be Edwin's girlfriend anymore since Edwin does not win the race. Thus, it makes Edwin curse Monica with the word fuck. The real meaning for the word fuck is actually to have sex with someone, but in this cas,e this word is used to express anger. Hence, fuck can be used as a noun or verb to express annoyance, contempt, or impatience. This word belongs to obscenity taboo word.

Figure 1

Types of Taboo Words in Fast \& Furious 1 and Fast \& Furious 7 


\section{Types of Taboo Words}

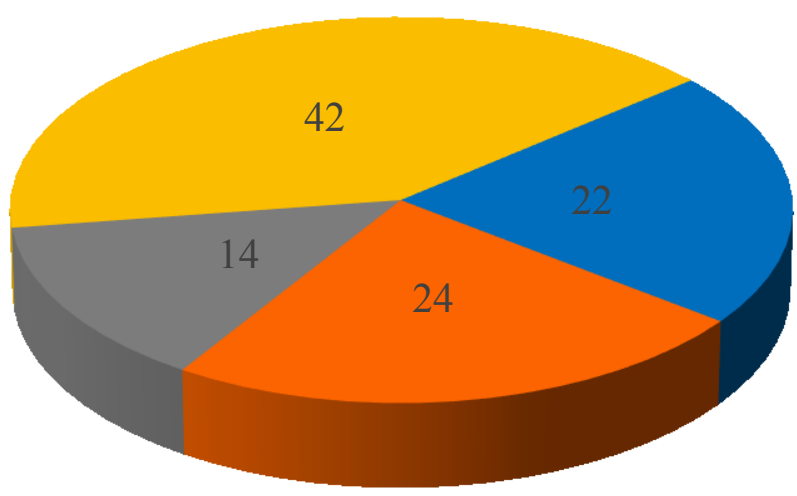

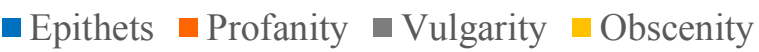

The data in Figure 1 indicate that obscenity is the type of taboo word mostly used by the characters in Fast and Furious 1 \& Fast and Furious 7 which cover 42 data. The second mostly used type of taboo word is hold by profanity with 24 data; the third category is epithets with 22 data; and the last category is vulgarity with 14 data. This calculation is irrespectively based on the factor of the difference between the male and female characters and the social classes in the United States.

Table 1

The Distribution of Taboo Words Used by Social Class in Male-Female Characters of Fast and Furious 1 (2001)

\begin{tabular}{lllllll}
\hline \multirow{3}{*}{ Gender } & \multirow{2}{*}{$\begin{array}{l}\text { Social } \\
\text { Class }\end{array}$} & \multicolumn{5}{c}{ Type of Taboo Words } \\
\cline { 3 - 6 } & Epithets & Profanity & Vulgarity & Obscenity & Total \\
\hline \multirow{4}{*}{ Male } & UC & - & - & - & - & - \\
& MC & 1 & 5 & 2 & 7 & 15 \\
& WC & 5 & 7 & 3 & 17 & 32 \\
\hline
\end{tabular}




\begin{tabular}{lllllll}
\hline & UC & - & - & - & - & - \\
\multirow{2}{*}{ Female } & MC & - & 3 & - & 7 & 10 \\
& WC & 1 & - & 1 & - & 2 \\
& LC & - & - & - & - & - \\
\hline Total & & 7 & 15 & 6 & 31 & 59 \\
\hline
\end{tabular}

Table 2

The Distribution of Taboo Words Used by Social Class in Male-Female Characters of Fast and

Furious 7 (2015)

\begin{tabular}{lllllll}
\hline \multirow{2}{*}{ Gender } & \multirow{2}{*}{$\begin{array}{l}\text { Social } \\
\text { Class }\end{array}$} & Epithets & Profanity & Vulgarity & Obscenity & Total \\
\cline { 3 - 7 } & UC & - & - & - & - & - \\
\multirow{2}{*}{ Male } & MC & 13 & 8 & 6 & 9 & 36 \\
& WC & 1 & 1 & - & 1 & 3 \\
& LC & - & - & - & - & - \\
\hline \multirow{2}{*}{ Female } & UC & - & - & - & - & - \\
& MC & - & - & 2 & 1 & 3 \\
& WC & 1 & - & - & - & - \\
\hline \multirow{2}{*}{ Total } & LC & - & - & - & - & 43 \\
\hline
\end{tabular}

Table 1 shows that the most dominant taboo word used by the characters is obscenity type with 31 data and the least is vulgarity type with only 6 data. Both male and female characters tend to use obscenity in expressing their emotion. Obscenity refers to sexual activity with rough manner and if the word is said, it becomes the most offensive and it is rarely used in public (Batistella, 2005). However, the characters in Fast and Furious 1 prefers to use obscenity in their 
conversation. This is slightly different from Table 2. Table 2 indicates that epithets are taboo words that are most often used by both the male and female characters in Fast and Furious 7. Table 2 also shows that the female characters do not use profanity at all in expressing intentions. This is also different from the first table. The first table shows that female characters use all types of taboo word. Besides, as shown in Table 1 and Table 2, only the characters from the middle and working classes use taboo words in their conversation. Meanwhile, the upper-class characters rarely use taboo words in expressing their emotion. By such construction, these films underline the correlation between social class and morality values.

Finding which result from the analysis of both movies shows dissimilarity in terms of the use of taboo word. From Fast and Furious 1, the characters from working class more often use taboo words than characters from the other classes. However, Fast and Furious 7 presents the middle class characters who tend to use taboo words. It shows that within 15 years, there is a slightly change in the use of taboo words. This movie also presents the mobility of the social status of the characters from the working class into the middle class. However, in terms of communication style, the social mobility does not change their style of communication. Their habit of expressing their emotion with some taboo words persists, despite the shift of their social status.

Meanwhile, as depicted in Table 1, there is a significant difference between male and female characters in using taboo words. Male characters use 86 taboo words, yet female characters only utter 16 taboo words. Since most of the characters are male, the taboo words uttered by the characters mostly come from the male characters. Nonetheless, it is still possible for the female characters to utter taboo words in their conversation as the male characters do. 
Thus, it can be said that the male characters in these movies more frequently use taboo word than the female characters.

The data in Table 1 show that the most dominant type of taboo word uttered by the male and female characters is obscenity, referring to a sexual activity with rough manner (Batistella 2005), divided into 34 categories of this type. Obscenity is the most offensive and this type is very rarely used in the United States. However, the characters, both male and female, in these movies use obscenity in their conversation. Meanwhile, the last frequent taboo word used by the male characters is categorized into vulgarity, as many as 12 data, and 2 data are categorized into epithets used by female characters.

Table 3

Distribution of Social Class towards Taboo Words

\begin{tabular}{lccccc}
\hline \multirow{2}{*}{$\begin{array}{c}\text { Types of Taboo } \\
\text { Words }\end{array}$} & \multicolumn{5}{c}{ Social Class } \\
\cline { 2 - 6 } & Upper Class & Middle Class & $\begin{array}{c}\text { Working } \\
\text { Class }\end{array}$ & Lower Class & Total \\
\hline Epithets & - & 14 & 7 & - & 21 \\
\hline Profanity & - & 15 & 9 & - & 23 \\
\hline Vulgarity & - & 11 & 4 & - & 15 \\
\hline Obscenity & - & 24 & 18 & - & 42 \\
\hline Total & - & 64 & 38 & - & 102 \\
\hline
\end{tabular}


Figure 2 Distribution of Social Class towards Taboo

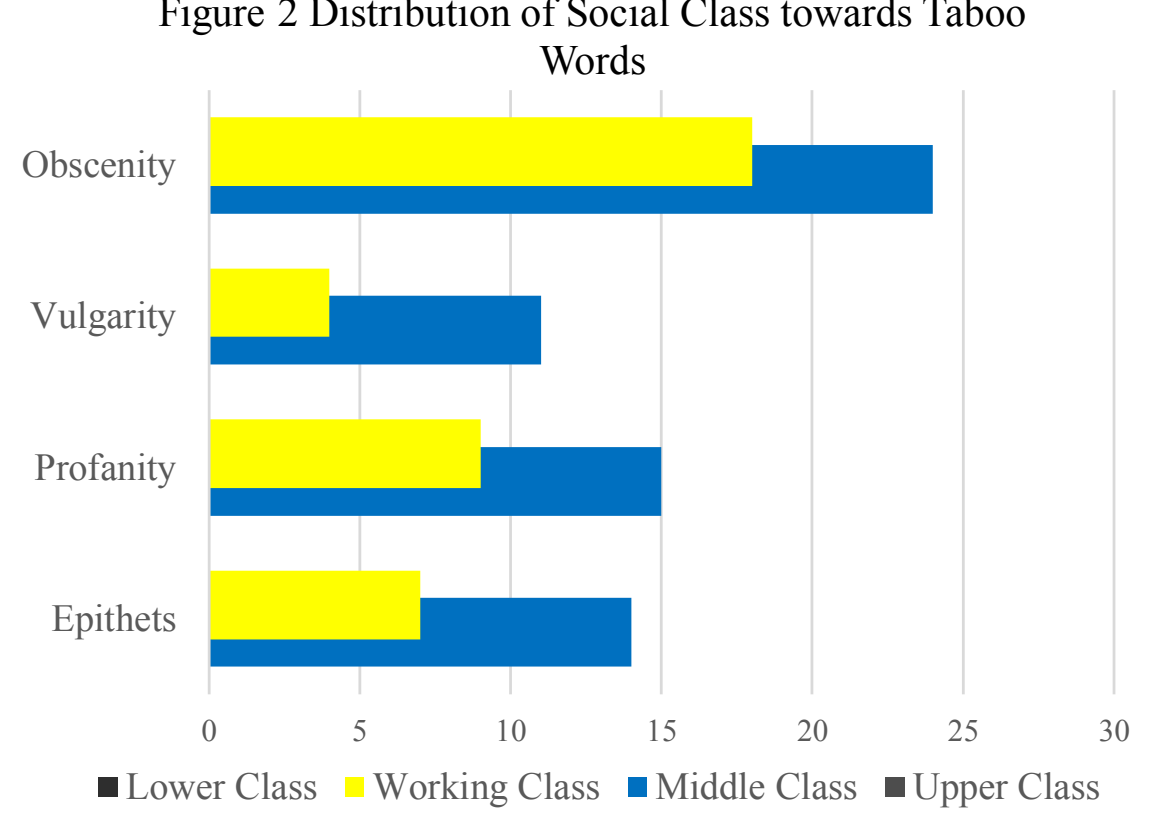

As can be seen in Table 3 and Figure 2, there are only two types of social classes who utter taboo words from four social classes. They are from the members of the middle class and the working class. Nonetheless, in these movies there is a character from the upper class, yet there are no characters from the member of the lower class. The people from the upper class do not use any type of taboo words in their conversation in order to build pace and keep their prudence.

Table 3 and figure 2 show that the middle class speaks taboo words more often than the working class: 64 data of taboo words uttered by middle class and 18 data of taboo words uttered by working class. Whereas, the comparison between middle class and working class in terms of the number of the use of each taboo word is directly proportional; the first is obscenity, the second is profanity, the third is epithets, and the last is vulgarity. Twenty four data are taken from the conversations between members of the middle class and 18 data are obtained from the members of the working class. It indicates that both the members of middle class and working 
class prefer to use obscenity type of taboo word. This number shows that the characters in these movies are more familiar with obscenity such as shit, fuck, bastard, suck, etc.

Furthermore, table 3 and figure 2 also show that the use of vulgarity taboo word is still low, whose number is only 15 data from the total of 102 data. Hence, the distribution is as follows: 11 data for middle class members and 4 data for working class members. It can indicate that the use of vulgarity is still avoided on its use. Based on Gilbert, vulgarity taboo word is the type of taboo language involving sexual anatomy. In the U.S. culture, mentioning sexual anatomy is considered as a big deal of problem (2005). Thus, in these movies, vulgarity is still low on its use.

\section{Discussion}

Obscenity word is an utterance that is very offensive to utter in terms of morality and it should not be used in public space when having conversation with other people (see Batistella 2005). However, the characters from these two movies use obscenity in expressing their emotion. Meanwhile, vulgarity is rarely used and positioned as the least type of taboo word used by the characters. The male characters tend not to use vulgar expression in their conversation. Another type of taboo, which is rarely used, is epithet. When it is used, the female characters tend not use it. The variation of usage between male and female indicates that there is a different perception between male and female in using taboo word. From the high frequency of the male characters of using taboo words in their conversations, the finding of the study still confirms to the previous finding that for the male, the use of taboo words are considered as natural and part of the male habit (Mohammadi, Roumiani, \& Tabari, 2014). Nonetheless, the female characters tend to rarely use taboo words in conversation because it is considered as unladylike. Expressing opinion with taboo words can lower woman's social status. However, this ethics does not work for male (Talbot, 2010). 
Talbot (2010) also contends that the female finds it difficult yet easy to lose social status. This case makes females need to be aware and signal their social status through their language of speaking. Thus, females tend to be careful in choosing their word choice to express their idea. Meanwhile, as further explained by Talbot, males do have more freedom on their word choices. For males it is more important to express their strong feelings, rather than word choice consideration which can hinder the message they want to say. Thus, males do not earn bad name when using taboo words in their conversation. Such concepts are all applied in the movie in the way to construct the male and female characters.

Based on the study on the films there is a significant difference between male and female in using taboo words and so is in other films. This research acknowledges no significant finding to the contribution to the academic discussion on the difference between male and female in using taboo words. This research has taken two different films produced in different year. This statement has the same finding as Sherafat and Soori (2015) and Hui-Ling and Talley (2012). In their research, they carry out that male and female differences have any role in uttering taboo words and claim that females tend to use taboo words less than males. Moreover, Hu-Ling and Talley (2012) asserts that taboo words are solely used by males, and also asserts that females who use taboo words are still judged as being inappropriate in behavior. In fact, from the results, it still shows that females use taboo words even if it is not as much as males does.

The obtained results also counter to de Klerk's (1992) study, that females want a freedom in their right to use taboo words terms. De Klerk has said that females have the same right as males in using taboo words in their conversation (1992). Taboo words are still found to be expressed by female characters in these movies since the female characters have the main role in these movies, so that they need to emphasize their words through certain taboo words. 
Meanwhile, as the finding of the previous research shows, the female characters speak taboo words found in these movies indicate that females know taboo words but rarely use them (see Bayar \& Krishnayya, 2001).

As it can be seen in the results, it is found that two social classes use taboo words in their conversation, namely middle class and working class. People from upper class do not seem to use taboo words in their conversation since they always appear in a formal situation in these movies. They want to build their image and put themselves in the right place. Besides, these movies just show the characters from upper class, middle class, and working class. There is no character from lower class. That is why there are no scene of people from upper class and working class who use taboo words in their conversation.

Basically, the lower-class has a tendency to swear the most and the middle class has a tendency to swear the least (Jay, 1992). Jay has further explained that the lower-class members do not have power and do not have anything to lose, so they swear freely. While the middle class members have the most to lose and they do not have the same power and prestige as upper class so that they will swear the least. If the members of middle class swear too much, they will lose their status in front of others or simply seen as being too much like the lower class (1992). Yet, in these movies the middle class members are the one who use taboo words more often than others. People from middle class in these movies mostly use obscenity taboo word. It is clearly not in line with Jay's (1992) finding.

This article finds that obscenity is the most offensive taboo word in the United States, especially for adults and matures in all the time no matter in which era, country or culture because it is connected with sexual activity (Batistella, 2005). According to Ekstrom (2008), the use of sexual activity phrase is the most avoided taboo topic by people in their conversation in 
the United States. Thus, obscenity is the cruelest type of taboo word, and it is better to avoid it. Otherwise, the use of obscenity taboo word is still high if we compare to Ekstrom's idea about obscenity word.

This phenomenon can be caused by some factors such as education, age, culture, social class, and even gender. Based on these movies, the surrounding environment which is hard and full of competition makes the characters seem accustomed to use taboo words, even very offensive taboo words. An example of this case is Edwin, the character from the middle-class member, who says "You see that shit? He is got enough NOS in there to blow himself up". He is a member of middle class who uses taboo word shit as obscenity type to refer something awesome, called NOS, yet he does not intend to say something disgusting.

\section{Conclusion}

There are four types of taboo words expressed by the characters found in these movies; epithets, profanity, vulgarity, and obscenity. The major finding is that obscenity type is the dominant taboo word uttered by the characters. Obscenity becomes the most frequently used taboo words because the characters think it is the most effective way to insult someone. Thus, obscenity can deteriorate other people's pride so that they succeed to hurt other people's feeling. On the other hand, the least frequently use taboo word is vulgarity. Sexual anatomy is still strongly prohibited things to mention because this can be categorized as sexual harassment in many places, especially in the United States.

The findings of this study confirm that both male and female characters utter taboo words, even though male characters utter taboo words more often than female characters. Furthermore, this study confirms Sherafat and Soori's (2015) and Hui-Ling and Talley's (2012) findings that females use taboo words as males do. Hence, this study also confirms de Klerk's (1992) study 
that there is no standard stereotype about women's use of taboo words in society. Women use taboo words to gain their freedom in speaking or having a conversation.

Based on the results and discussion, there are two social classes that use taboo words in their conversation in these movies, the middle class and the working class. The middle-class members are the ones who use taboo words more often than the working-class members. Thus, it can be concluded that this study does not confirm Jay's (1992) findings that have mentioned if the middle class has the tendency to keep their image so that they use the least taboo words. 


\section{References}

Anderesson, L., \& Trudgill, P. (1990). Bad language. Oxford: Basil Blackwell.

Batistella, E.L. (2005). Bad language: Are some words better than others?. New York: Oxford University Press.

Bayard, D., \& Krishnaya, S. (2001). Gender, expletive use, and context: Male and female expletive use in structured and unstructured conversation among New Zealand university students. Women and Language, 26(1), 1-15.

Chaika, E. (1998). Dangerous English 2000 (3rd ed.). USA: Delta Publishing Company.

De Klerk, V. (1992). How taboo are taboo words for girls?. Language in Society, 21, 277-289. doi: $10.1017 / \mathrm{S} 0047404500015293$

Ekstrom, A. (2008). Taboo language in sex and the city. Sweden: Kristianstad University.

Gao, C. (2013). A sociolinguistic Study of English Taboo Language. Theory and Practice in Language Studies, 3(12), 2310-2314. Doi: 10.4304/tpls.3.12.2310-2314

Gilbert, D. (2005). The American class structure: In an age of growing inequality (6th ed.). Thousand Oaks, CA: Pine Forge Press.

Jay, T. (1992). Cursing in America. Philadelphia: J. Benjamins Pub. Co.

Keturi, S., \& Lehmonen, T. (2012). Thou shalt not write about: A study of taboo content in finnish efl textbooks for upper secondary school. Finland: University of Jyvaskyla.

Ling, T.H., \& Talley, P.C. (2012). The Influence of gender differences in proscribed language use in Taiwan. International Journal of Business and Social Science, 3(2), 167-172.

McQuail, D. (2010). Mass Communication Theory (6th ed.). London: Sage Publication. 
Mbaya, N. (2002). Linguistic taboo in African marriage context: A study of oromo laguu. Nordic Journal of African Studies, 11, 224-235. http://www.njas.helsinki.fi/pdf files/vol1 1 num2/mbaya.pdf.

Mohammad, J.M., Roumiani, M., \& Tabari, B.H. (2014). Gender tendency towards using taboo words among university students. Journal of Advances in Linguistics, 3(2), 203-207.

Shobur, A. (2004). Semiotika komunikasi. Bandung: Remaja Rosdakarya.

Soori, A., \& Sherafat, Z. (2015). Iranian efl learners' perception of english taboo words. International Journal of English and Education, 4(2), 67-74.

Stapleton, K. (2003). Gender and swearing: A community practice. Women Language. 26 (2).

Surakhmad, W. (1994). Metode penelitian kualitatif: Dasar teori dan penerapannya dalam penelitian. Surakarta: UNS Press.

Talbot, M. (2010). Language and gender (2nd ed.). Cambridge: MA. Polity Press.

The Fast and The Furious. (n.d.). Retrieved from https://www.rottentomatoes.com/franchise/the_fast_and_the_furious/ 